\title{
Use of native milk whey in the production of smoked-boiled chicken ham
}

\author{
Rinat H. Baimishev*, Lidia A. Korosteleva, Tatyana N. Romanova, Irina V. Suhova, and Elena V. Dolgosheva \\ Samara State Agrarian University, 446442 Kinel, Samara region, Russia
}

\begin{abstract}
The purpose of this research is to determine the possibility of the use of native milk whey in the production of smoked-boiled ham from poultry meat. During the research, the process of modeling the production of smoked-boiled ham with the use of native milk whey was simulated. As a result of the studies, it was found that in the development of meat products, the whey had a positive effect on organoleptic, physico-chemical parameters, as well as the yield of finished products, which ultimately determines the feasibility and economic efficiency of the use of whey in the recipe of processed products.
\end{abstract}

\section{Introduction}

In the context of modern ideas about balanced nutrition, the expansion of the assortment of meat products should be accompanied by the creation of new types of products. The solution to this problem is facilitated by the use of dairy types of raw materials, which make it possible to increase the mass content of protein in meat products. The use of whey products is a new direction. The introduction of whey into meat products improves their quality and taste $[1,2]$.

Milk whey is a by-product in the production of cheeses, cottage cheese, and casein and is a secondary milk raw material. Depending on the type of product, cheese, curd and casein whey are distinguished. The composition of whey is determined by the type of main product and the technology for its production. In the production of certain types of cheeses (Russian, Poshekhonsky, etc.), about $30 \%$ of the whey is salty [3, 4]. The salt content in salted cheese whey is $0.5-4.0 \%$.

Milk whey contains all the essential amino acids. The total content of free amino acids in whey (in $\mathrm{mg} / \mathrm{l}$ ): cheese - 132.7, cottage cheese - 450.0; in whey proteins: raw cheese - 6490, cottage cheese - 5590. Whey carbohydrates are represented mainly by lactose (90\%). Such monosugars as glucose and galactose were found in whey. Curd whey contains $0.7-1.6 \%$ of glucose, which is due to the hydrolysis of lactose in the production of cottage cheese, and cheese whey - trace. Milk whey contains $0.05-0.45 \%$ of fat, with more fat dispersed in whey than in milk. Whey collects almost all salts and trace elements of milk, as well as salts introduced during the production of the main product. The absolute content (in $¥ \%$ ) of the main ash elements in whey is as follows: potassium - 0.09-0.19, magnesium 0.009-0.02, calcium
0.04-0.11, sodium 0.03-0.05, phosphorus 0.04-0.10, chlorine 0.08-0.11.

The energy value of whey is $36 \%$ of the energy value of cow milk, and their biological value is approximately the same $x$ [5-7].

With the seeming simplicity of using unprocessed whey as an ingredient in food products, it is necessary to admit that it is not so simple. For example, the attempts to use curd whey for the production of meat products are not widespread, due to the high acidity that adversely affects meat proteins. At the same time, the use of whey is possible to solve the problem of deficiency of animal protein $[8,9]$.

In this regard, the purpose of the research is to determine the effect of native milk whey on the quality of the smoked-boiled ham from poultry meat.

In order to achieve this purpose it is necessary to solve the following tasks:

- To analyze the scientific and technical literature on nutritional value and the use of whey in meat industry;

- To determine the effect of whey on the organoleptic and physico-chemical quality indicators of smokedboiled ham;

- To develop a technology for the production of smoked-boiled ham using native milk whey;

- To determine the economic efficiency of the production of smoked-boiled ham using native milk whey.

\section{Materials and methods}

\subsection{Research object}

The following objects were chosen as research objects: broiler chicken meat in accordance with State Standard 31962-2013 with EE marking (drawn), experimental

\footnotetext{
* Corresponding author: baimishev@mail.ru
} 
variants of smoked-boiled ham in accordance with TU 9213-057-51024574-13, under the conditions of the laboratory of the faculty of technology of Samara State Agrarian University [12]. The brines were prepared in order to study the effect of native milk whey on the quality of smoked-boiled ham. The injection level of smoked-boiled ham was $25 \%$. The recipes of the experimental variants of smoked-boiled ham are presented in Table 1. The studies of the effect of native milk whey on the quality of smoked-boiled ham were carried out in several stages.

At the first stage, the raw materials for the production of smoked-boiled ham were investigated.

The variant without whey was selected as a control experiment. In this experiment, nitrite-curing mix, phosphate and sodium chloride, flavoring additive "Roasted chicken", and ground black pepper were added.

In the second variant, native milk whey was added in the amount of $5 \%$, and in the third variant, whey was added in the amount of $10 \%$. In the fourth variant, native whey was added in the amount of $15 \%$, and in the fifth variant, native whey was added in the amount of $20 \%$.

Table 1. The recipes of smoked-boiled ham with the addition of native milk whey according to the experimental options (per $100 \mathrm{~kg}$ of unsalted raw materials)

\begin{tabular}{|l|c|c|c|c|c|}
\hline \multirow{2}{*}{$\begin{array}{l}\text { Food and raw } \\
\text { materials }\end{array}$} & $\begin{array}{c}\text { Emoked- } \\
\text { boiled } \\
\text { ham } \\
\text { without } \\
\text { milk whey } \\
\text { (control) }\end{array}$ & $\begin{array}{c}\text { Smoked } \\
\text {-boiled } \\
\text { ham } \\
\text { with } \\
\text { whey }\end{array}$ & $\begin{array}{c}\text { Smoked } \\
\text {-boiled } \\
\text { ham } \\
\text { with } \\
10 \% \\
\text { milk }\end{array}$ & $\begin{array}{c}\text { Smoked } \\
\text {-boiled } \\
\text { ham } \\
\text { with } \\
15 \% \\
\text { milk }\end{array}$ & $\begin{array}{c}\text { Smoke } \\
\text { d- } \\
\text { boiled } \\
\text { ham } \\
\text { with } \\
20 \%\end{array}$ \\
\hline \multicolumn{5}{|c|}{ Raw material, kg/100 kg } \\
\hline $\begin{array}{l}\text { Smoked-boiled } \\
\text { chicken ham }\end{array}$ & 100.00 & 100.00 & 100.00 & 100.00 & 100.00 \\
\hline Total & 100.00 & 100.00 & 100.00 & 100.00 & 100.00 \\
\hline $\begin{array}{l}\text { Spices and material, kg/100 kg of raw material } \\
\text { nitrite-curing } \\
\text { mix }\end{array}$ & 2.50 & 2.50 & 2.50 & 2.50 & 2.50 \\
\hline $\begin{array}{l}\text { flavoring } \\
\text { additive } \\
\text { "Roasted } \\
\text { chicken" }\end{array}$ & 0.20 & 0.20 & 0.20 & 0.20 & 0.20 \\
\hline $\begin{array}{l}\text { ground black } \\
\text { pepper }\end{array}$ & 0.10 & 0.10 & 0.10 & 0.10 & 0.10 \\
\hline phosphate & 0.30 & 0.30 & 0.30 & 0.30 & 0.30 \\
\hline Milk whey & - & 5.00 & 10.00 & 15.00 & 20.00 \\
\hline
\end{tabular}

For the production of smoked-boiled ham, broiler meat was pre-chopped, then the resulting chicken legs were sprinkled with a brine containing 5,10,15 and $20 \%$ natural milk cheese whey in its natural state. The injection level for all experimental variants was $25 \%$.

Ambassador of raw materials was carried out using multi-needle injectors, for which one also needs to prepare a brine. The brine was prepared in stainless steel containers by sequentially dissolving the ingredients with vigorous stirring.
At the first stage, whey was poured, then salt was dissolved in water, as the first ingredient. Then, after its complete dissolution, the remaining ingredients were added. The brine was prepared chilled to the temperature of $2-40{ }^{\circ} \mathrm{C}$, so $10-15 \%$ of the water was replaced with ice. After this, the mixture was thoroughly mixed until all the ingredients were completely dissolved.

After the analysis of the obtained data, the option with the best properties was selected and recommendations for production were given.

\subsection{Water binding powered}

The water-binding power was determined by the pressing method, based on the release of water by the test sample during easy pressing, sorption of the released water by filter paper and determination of the amount of separated moisture to the spot area left by it on the filter paper. The reliability of the results was proved by triplicate determinations.

During the determination of water-binding power, a sample of a product weighing $0.3 \mathrm{~g}$ was weighed on a circle of polyethylene with a diameter of $20 \mathrm{~mm}$, and then transferred to an ash-free filter placed on a glass plate so that the sample was under the circle.

The sample was covered from above with the same plate as the lower one, set a weight of $1 \mathrm{~kg}$ on it and held for 10 minutes. After that, the filter with a sample was freed from the load and the lower plate, and then outlined the contour of the spot around the compressed meat piece with a pencil. The external contour was drawn when the filter paper dried in air.

The size of the wet spot (external) was determined by the difference between the total area of the spot and the weight of the sample.

It was experimentally established that $1 \mathrm{~cm}^{2}$ of wet filter area corresponds to $8.4 \mathrm{mg}$ of moisture.

$$
\mathrm{BCC}=(\mathrm{X}-8.4 * \mathrm{~S} / \mathrm{X}) * 100 \% \text {, }
$$

where $\mathrm{X}$ - mass content of bound moisture in the product, $\%$ of total moisture; $\mathrm{M}$ - total moisture mass in the sample, $\mathrm{mg} ; \mathrm{S}$ - wet spot area, $\mathrm{mg}$.

\section{Results}

At the initial stage, before developing experimental options, the quality of the feedstock was investigated.

The results of organoleptic evaluation showed that the beak of carcasses of the bird is elastic, dry and glossy, the mucous membrane of the oral cavity is pale pink, slightly moistened, there is no extraneous odor; eyeballs are convex and fill the orbit.

The carcasses met the requirements for fresh meat, namely: the surface of the carcass is dry, yellowish; pale yellow fat; the serous membrane of the abdominal cavity is shiny, without mucus and mold; the muscles are elastic, slightly moist on the cut; during cooking, the broth is transparent, aromatic, which indicates that the carcasses used to make products correspond to a young bird. At the same time, the carcass bone (keel) of the carcass is not ossified (cartilaginous), and the skin is soft, elastic. 
During a superficial examination of poultry carcasses, no remains of a feather, hemp, or remains of internal organs were noted. According to their fatness and quality of processing, carcasses of the bird correspond to the first category.

At the same time, well-developed muscles (a rounded chest shape) and deposits of subcutaneous fat in the lower abdomen were noted. The mass of poultry carcasses was in the range $1.2 \ldots 1.4 \mathrm{~kg}$.

The color of the meat in the section was characteristic of this type of bird, without bruises, bruising, and a pale pink hue. The smell of meat corresponded to this type of bird, without extraneous odors. Particular attention was paid to the smell of layers of muscle tissue adjacent to the bone.

To assess the suitability of poultry meat for the production of smoked-boiled chicken legs, its hydrogen index was also determined. It amounted to 5.8 units, which corresponds to fresh meat, and the meat belongs to the category (NOR-normal).

The results of physico-chemical indicators are presented in Table 2. It is known that the physicochemical parameters of smoked-boiled ham (humidity, moisture-binding power) have a significant impact on the properties of the finished product [15].

According to the current regulatory technical documentation, the content of the mass of protein should not be less than $14 \%$, and the content of the mass of fat should not be more than $23 \%$.

After the analysis of the obtained data, it was found that almost all experimental variants of smoked-boiled ham meet the requirements of TU 9213-057-5102457413 in terms of the mass content of protein and fat.

The mass content of protein tended to increase with increasing levels of introduced whey from 23.59 in the control variant to $29.23 \%$ in the experimental variant where $20 \%$ of whey was added. The mass content of fat, on the contrary, decreased, in the control variant this indicator corresponded to $10.56 \%$, and in the variant where milk whey was added it was slightly lower $3.89 \%$.

At the same time, the indicator of the mass content of moisture did not have a definite dependence and varied within $59.04-65.2 \%$, probably due to the heterogeneity of the meat composition and the experimental error.

The moisture-binding power also changed insignificantly and ranged from 76.74 to $77.52 \%$, the $\mathrm{pH}$ was less than 5.5 units ranging from 5.36 to 5.47 which are probably due to the presence of acidic and neutral phosphates in the recipe.

The results of the organoleptic evaluation of the studied smoked-boiled chicken ham showed that the evaluation of the studied experimental variants in appearance showed that all the experimental variants are characterized as very attractive and received a rating from 8.71 to 8.86 points.

The color in the context of the experimental variants did not practically differ from each other and got a score of 8.57-8.86 points, with the exception of the variant with $15 \%$ whey, where this indicator was slightly lower and was at the level of 8.29 points.
Table 2. Physico-chemical quality indicators of smoked-boiled ham with a different level of native milk whey

\begin{tabular}{|c|c|c|c|c|c|c|}
\hline \multirow[b]{2}{*}{ Item } & \multirow[b]{2}{*}{$\begin{array}{c}\text { Norm } \\
\text { according } \\
\text { to TU } \\
9213-057- \\
51024574- \\
13\end{array}$} & \multicolumn{5}{|c|}{ Smoked-boiled chicken ham } \\
\hline & & $\begin{array}{c}\text { Smoked } \\
\text {-boiled } \\
\text { ham } \\
\text { without } \\
\text { milk } \\
\text { whey }\end{array}$ & $\begin{array}{l}\text { with } \\
5 \% \\
\text { milk } \\
\text { whey }\end{array}$ & $\begin{array}{l}\text { with } \\
10 \% \\
\text { milk } \\
\text { whey }\end{array}$ & $\begin{array}{l}\text { with } \\
15 \% \\
\text { milk } \\
\text { whey }\end{array}$ & $\begin{array}{l}\text { with } \\
20 \% \\
\text { milk } \\
\text { whey }\end{array}$ \\
\hline $\begin{array}{l}\text { Mass } \\
\text { content of } \\
\text { moisture, } \\
\% \\
\end{array}$ & Not rated & 63.98 & 65.2 & 59.04 & 62.27 & 64.75 \\
\hline $\begin{array}{l}\text { Mass } \\
\text { content of } \\
\text { protein, \% }\end{array}$ & $\begin{array}{l}\text { Not less } \\
\text { than } 14\end{array}$ & 23.59 & 25.28 & 26.91 & 27.4 & 29.23 \\
\hline $\begin{array}{l}\text { Mass } \\
\text { content of } \\
\text { total ash, } \\
\% \\
\end{array}$ & Not rated & 1.87 & 2.00 & 2.33 & 1.73 & 2.13 \\
\hline $\begin{array}{l}\text { Mass } \\
\text { content of } \\
\text { fat, } \%\end{array}$ & $\begin{array}{c}\text { Not more } \\
\text { than } 23\end{array}$ & 10.56 & 7.52 & 11.72 & 8.6 & 3.89 \\
\hline $\begin{array}{l}\text { Moisture- } \\
\text { binding } \\
\text { power, \% }\end{array}$ & Not rated & 76.82 & 77.11 & 76.79 & 77.52 & 76.74 \\
\hline $\begin{array}{l}\text { Hydrogen } \\
\text { value }\end{array}$ & Not rated & 5.36 & 5.40 & 5.47 & 5.37 & 5.44 \\
\hline
\end{tabular}

Table 3. Organoleptic evaluation of chicken and smoked chicken legs using native serum according to the results of the tasting commission

\begin{tabular}{|c|c|c|c|c|c|}
\hline \multirow[b]{2}{*}{ Item } & \multicolumn{5}{|c|}{ Smoked-boiled chicken ham } \\
\hline & $\begin{array}{c}\text { Smoked- } \\
\text { boiled ham } \\
\text { without } \\
\text { milk whey }\end{array}$ & $\begin{array}{c}\text { with } 5 \% \\
\text { milk } \\
\text { whey }\end{array}$ & $\begin{array}{l}\text { with } \\
10 \% \\
\text { milk } \\
\text { whey }\end{array}$ & $\begin{array}{l}\text { with } \\
15 \% \\
\text { milk } \\
\text { whey }\end{array}$ & $\begin{array}{l}\text { with } \\
20 \% \\
\text { milk } \\
\text { whey }\end{array}$ \\
\hline $\begin{array}{l}\text { External } \\
\text { view }\end{array}$ & $\begin{array}{c}8.86 \\
\pm 0.38 \\
\end{array}$ & $\begin{array}{c}8.71 \\
\pm 0.76 \\
\end{array}$ & $\begin{array}{c}8.86 \\
\pm 0.38 \\
\end{array}$ & $\begin{array}{c}8.71 \\
\pm 0.76 \\
\end{array}$ & $\begin{array}{c}8.71 \\
\pm 0.76 \\
\end{array}$ \\
\hline $\begin{array}{l}\text { Cutaway } \\
\text { color }\end{array}$ & $\begin{array}{c}8.71 \\
\pm 0.76 \\
\end{array}$ & $\begin{array}{c}8.57 \\
\pm 0.79 \\
\end{array}$ & $\begin{array}{c}8.86 \\
\pm 0.38 \\
\end{array}$ & $\begin{array}{c}8.29 \\
\pm 0.49 \\
\end{array}$ & $\begin{array}{c}8.29 \\
\pm 0.49 \\
\end{array}$ \\
\hline $\begin{array}{l}\text { Smell } \\
\text { (aroma) }\end{array}$ & $\begin{array}{c}8.71 \\
\pm 0.76 \\
\end{array}$ & $\begin{array}{c}8.86 \\
\pm 0.38 \\
\end{array}$ & $\begin{array}{c}8.86 \\
\pm 0.38 \\
\end{array}$ & $\begin{array}{c}8.71 \\
\pm 0.76 \\
\end{array}$ & $\begin{array}{c}8.71 \\
\pm 0.76 \\
\end{array}$ \\
\hline Taste & $\begin{array}{c}8.86 \\
\pm 0.38 \\
\end{array}$ & $\begin{array}{c}8.71 \\
\pm 0.76 \\
\end{array}$ & $\begin{array}{c}8.86 \\
\pm 0.38 \\
\end{array}$ & $\begin{array}{r}8.29 \\
\pm 0.49 \\
\end{array}$ & $\begin{array}{r}8.29 \\
\pm 0.49 \\
\end{array}$ \\
\hline $\begin{array}{l}\text { Consistenc } \\
\mathrm{y}\end{array}$ & $\begin{array}{c}8.43 \\
\pm 0.53 \\
\end{array}$ & $\begin{array}{c}8.86 \\
\pm 0.38 \\
\end{array}$ & $\begin{array}{c}8.86 \\
\pm 0.38 \\
\end{array}$ & $\begin{array}{c}8.71 \\
\pm 0.76 \\
\end{array}$ & $\begin{array}{c}8.71 \\
\pm 0.76 \\
\end{array}$ \\
\hline Juiciness & $\begin{array}{c}8.43 \\
\pm 0.53 \\
\end{array}$ & $\begin{array}{c}8.57 \\
\pm 0.79 \\
\end{array}$ & $\begin{array}{c}8.71 \\
\pm 0.76 \\
\end{array}$ & $\begin{array}{c}8.71 \\
\pm 0.76 \\
\end{array}$ & $\begin{array}{c}8.71 \\
\pm 0.76 \\
\end{array}$ \\
\hline $\begin{array}{l}\text { Overall } \\
\text { quality } \\
\text { score }\end{array}$ & 52.00 & 52.28 & 53.01 & 51.42 & 51.42 \\
\hline
\end{tabular}

In terms of smell and flavor, the developed experimental variants had no significant differences, 8.71 and 8.86 points for the experimental variants. By consistency, the lowest score was in the control variant 8.43 points. In terms of juiciness, the experimental variants were close, juiciness increased with the level of whey from 8.43 points in the control variant to 8.71 points in variants with 10,15 and $20 \%$ whey. In terms of taste, the control variant and the variant with the introduction of $10 \%$ whey were the best. The smallest total score was given to the following variants: control (52 points) and smoked-boiled chicken ham with milk 
whey of 15 and $20 \%$ (51.42 points). The variant with $10 \%$ whey received the highest score -53.01 points.

Table 4. Color characteristics of semi-smoked sausages with various application of whey

\begin{tabular}{|c|c|c|c|}
\hline Experience option & 1 & $\mathrm{a}$ & $\mathrm{b}$ \\
\hline $\begin{array}{l}\text { Smoked-boiled ham without } \\
\text { milk whey }\end{array}$ & 63.0 & 21 & 8.8 \\
\hline $\begin{array}{l}\text { Smoked-boiled chicken ham } \\
\text { with } 5 \% \text { milk whey }\end{array}$ & 62.0 & 23 & 7.0 \\
\hline $\begin{array}{l}\text { Smoked-boiled chicken ham } \\
\text { with } 10 \% \text { milk whey }\end{array}$ & 58.3 & 25.5 & 6.7 \\
\hline $\begin{array}{l}\text { Smoked-boiled chicken ham } \\
\text { with } 15 \% \text { milk whey }\end{array}$ & 58.2 & 25.4 & 6.4 \\
\hline $\begin{array}{l}\text { Smoked-boiled chicken ham } \\
\text { with } 20 \% \text { milk whey }\end{array}$ & 57.6 & 27.6 & 4.6 \\
\hline
\end{tabular}

The results of the study of the effect of whey on the color characteristics of chicken and smoked chicken legs are presented in table 4 .

As a result of the study of smoked and boiled chicken legs by color characteristics in the CIELab system, it was found that when 5,10,15 and 20\% of whey were added, the luminosity index "L" decreased by 5.4 and the yellowness index " $\mathrm{b}$ " - by 4.7 , and the redness index "a" increased by 6.6 .

In general, we can conclude that the addition of milk whey in the production of smoked and boiled chicken legs increases the color intensity. Probably, this effect is achieved due to the presence of lactose in whey.

The analysis of the results of the output of smokedboiled chicken legs showed that the introduction of milk whey increases the yield of the finished product, the output level of the smoked-boiled chicken legs was in the control version at the level of $80.5 \%$, and when the whey was added in the amount of $20 \%-82.8 \%$.

\section{Conclusion}

As a result of the study on the determination of the effect of native milk whey on the quality of smoked-boiled ham from poultry meat, the following was performed:

1. The analysis of the information data allowed concluding that the whey proteins of milk are used as meat-substituting ingredients in the production of meat products.

2. The results of the organoleptic evaluation of the studied smoked-boiled chicken ham showed that in appearance, color and flavor all the experimental options practically do not differ from each other. The control variant received the least number of scores in terms of consistency and juiciness. The best ones in terms of taste were control variant and the variant with $10 \%$ whey. The variant with $10 \%$ whey received the highest total score 53.01 points. It was found that the use of native milk whey in the amount of up to $20 \%$ in the mix of the brine for the injection of smoked-boiled chicken ham allows getting the finished product with good physico-chemical characteristics. The mass content of protein tended to increase with increasing levels of introduced whey from
23.59 in the control variant to $29.23 \%$ in the experimental variant in which $20 \%$ whey was added.

3 . The technology for the production of smokedboiled ham from poultry meat should include the following operations: butchering, preparation of brine, raw salting, strapping, drying, smoking, cooking, cooling, quality control, storage. The pickling of raw materials should be carried out using multi-needle injectors, for which it is also needed to prepare brine. At the first stage, whey is poured and then it is necessary to dissolve the salt in water, as the first ingredient. Then, after its complete dissolution, the remaining ingredients can be added. The brine should be prepared chilled to a temperature of $2-40{ }^{\circ} \mathrm{C}$. Therefore, $10-15 \%$ of the water can be replaced with ice.

4. It was found that the cost of chicken ham according to the proposed technology is 206.22 rubles / $\mathrm{kg}$, and according to the existing technology it is 204.48 rubles / $\mathrm{kg}$. The amount of additional profit from the sale of $1000 \mathrm{~kg}$ of smoked-boiled ham from poultry with the introduction of native milk whey will be 1.74 thousand rubles. The level of profitability of the proposed technology is $22.26 \%$, while with the existing technology it is $21.23 \%$. Consequently, the production of smoked-boiled ham from poultry meat with the addition of native milk whey is economically viable.

\section{References}

1. D.V. Zipaev, A.V. Zimichev, Milk whey - a valuable raw material for recycling News of universities. Food technology 2, 14-16 (2007) Retrieved from: https://e.lanbook.com/journal/issue/290196.

2. A.G. Khramtsov, Innovative developments in the use of whey Technique and technology of food production 3, 5-15 (2018) Retrieved from: https://e.lanbook.com/journal/ issue/310059.

3. E.A. Kosheleva, N.B. Gavrilova, D.M. Violets, The use of electromagnetic processing in the technology of fermented additives based on whey Agrarian Bulletin of the Urals 11, 41-44 (2013) Access mode: https://e.lanbook.com/journal/issue/289922.

4. A.V. Krieger, Yu.G. Sturova, The use of cheese whey for the production of vitamin drinks, as a factor in increasing the competitiveness of the enterprise Polzunovsky Bulletin 3, 18-22 (2016) Retrieved from: https://e.lanbook.com/journal/issue/ 302105.

5. M. Dogka, O. Aikush, Effective processing of whey Milk processing: technology, equipment, products 7 , 42-42 (2016) Retrieved from: https://rucont.ru/efd/ 507311

6. P.G. Nesterenko, Production of condensed concentrates based on whey News of universities. Food technology 2, 5-10 (1992) Access mode: https://e.lanbook.com/ journal/issue/289990.

7. S.V. Rezunenko, To the question of the rationality of whey processing Milk processing: technology, equipment, products 8, 54-55 (2015) Retrieved from: https://rucont.com/efd/587840 
8. L.S. Kudryashov et al., Functional and technological properties of a complex of animal proteins Bulletin of the South Ural State University. Series: Food and Biotechnology 2, 17-24 (2017) Retrieved from: https://e.lanbook.com/journal/issue/ 308258.
9. G.V. Menh, I.S. Razumnikova, Study of the terms of helo-formation of milk whey Technique and technology of food production 4, 33-37 (2010) Retrieved from: https://e.lanbook.com/journal/ issue $/ 286867$ 